\title{
High latitude winter sightings of common minke whale calves (Balaenoptera acutorostrata) in the Northeast Atlantic
}

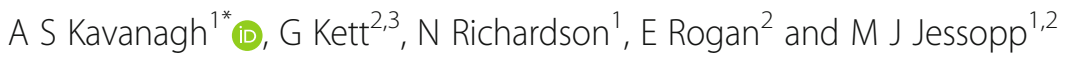

\begin{abstract}
Although common minke whales occur in relatively high numbers in the North Atlantic, relatively little is known about their seasonal movements or the location of their breeding and calving grounds. This lack of knowledge compromises our ability to protect potentially important areas for this species. Here we report high latitude winter sightings of unweaned minke whale calves recorded in offshore waters in the Northeast Atlantic. We discuss how such sightings may contribute to our understanding of the winter distribution and movements of this species; raising the possibility that a proportion of the population may over-winter at high latitudes in offshore waters, and that calving may occasionally occur in the warm North Atlantic Drift waters of western Europe's continental shelf.
\end{abstract}

Keywords: Minke whale, Balaenoptera acutorostrata, Calf, Northeast Atlantic, North Atlantic drift

\section{Main Text}

Common minke whales (Balaenoptera acutorostrata acutorostrata, Lacépède, 1804) are one of the most abundant mysticetes in the North Atlantic and as a result, are currently listed as a species of Least Concern under the IUCN Red List (Reilly et al., 2008). The International Whaling Commission (IWC), an Inter-governmental Organisation charged with the conservation of whales and the management of whaling, recognises four minke whale stocks for management purposes in the North Atlantic: Central North Atlantic, West Greenland, Canadian East Coast, and Northeast Atlantic (Donovan, 1991), however, whales are thought to move extensively throughout the entire region (Anderwald et al., 2011). Recent minke whale abundance estimates suggest that there are approximately $107,205(\mathrm{CV}=0.14)$ individuals in the Northeast Atlantic and $18,958(\mathrm{CV}=0.347)$ animals in European Atlantic shelf waters (Skaug et al,, 2004; Hammond et al., 2013). After years of exploitation, an IWC agreed moratorium on commercial whaling was

\footnotetext{
* Correspondence: ailbheskavanagh@gmail.com

${ }^{1} \mathrm{MaREl}$ Centre, Environmental Research Institute, University College Cork,

Beaufort Building, Ringaskiddy, Co, Cork, Ireland

Full list of author information is available at the end of the article
}

adopted in 1982 to allow whale stocks to recover. However, despite this moratorium, minke whales continue to be caught commercially by a number of nations (under objection) in the North Atlantic, and they are also taken as part of a subsistence quota (IWC, 2018).

North Atlantic minke whales are well-studied on feeding grounds, and have been recorded in summer months off the coasts of Canada, Greenland, Iceland, Norway and the British Isles, as far north as the Barents Sea e.g. (Reilly et al., 2008; Macleod et al., 2004; Bartha et al., 2011; Bertulli et al., 2018; De Boer, 2010). In addition, summer sightings of minke whales have also been recorded in the English Channel, Celtic Sea and as far south as the Bay of Biscay (Hammond et al., 2013; Hammond et al., 2002; Laran et al., 2017). While migratory patterns of this species are generally poorly understood, they are believed to undertake large-scale seasonal migrations between summer feeding grounds at higher latitudes, and breeding grounds at lower latitudes in winter months (Risch et al., 2014; Vikingsson \& HeideJørgensen, 2015). Although there is no genetic evidence for geographic structure between the putative stocks in the North Atlantic (Anderwald et al., 2011; Quintela et al., 2014), minke whales are thought to distribute across at

(c) The Author(s). 2018 Open Access This article is distributed under the terms of the Creative Commons Attribution 4.0 International License (http://creativecommons.org/licenses/by/4.0/), which permits unrestricted use, distribution, and 
least two breeding grounds, however the location of these breeding grounds remains poorly known (Anderwald et al., 2011). The timing of migratory movements coupled with winter sightings of minke whales and calves in the Southern Northwest and Northeast Atlantic suggest that waters off the South-eastern U.S. and West Africa are important regions for these animals, and may include calving areas (Vikingsson \& Heide-Jørgensen, 2015; Mitchell, 1991; Nilsson et al., 2011). In addition, records of stranded calves and minke whales between 3 and $4.5 \mathrm{~m}$ in length in the Mediterranean (Fraija-Fernández et al., 2015) further support lower latitude calving for this species. Despite increasing evidence for these low latitude breeding grounds, occasional sightings of what are described as 'young calves' in British and Irish waters in spring and summer has led to speculation that some females may calve in these more northerly waters at this time of year (Anderwald \& Evan, 2007).

Available literature suggests that conception and birth in common minke whales likely occurs in winter months (October-March) with a peak in February (Lockyer, 1984; Sergeant, 1963), however, the timing of individual conception may vary (Larsen \& Kapel, 1982). Pregnancy rates suggest a calving interval between 1 and 2 years (Lockyer, 1981; Horwood, 1989) with gestation lasting approximately 10 months, and with new born calves ranging in length from 2.4 to $2.8 \mathrm{~m}$ (Sergeant, 1963; Horwood, 1989). Weaning occurs between 4 and 6 months, at lengths between 4.4 and $5.5 \mathrm{~m}$ (Christensen, 1981; Hauksson et al., 2011). Few published references to offshore minke whale calf sightings have been recorded for high latitudes in the North Atlantic, with none in winter months. Here we report on two sightings of minke whales with dependant calves in offshore waters of the Northeast Atlantic in winter, and we discuss the possibility that calving may occasionally occur in these more temperate waters.

On the 24th of March 2017 an adult minke whale accompanied by a very small calf was sighted on the Porcupine Bank in the Northeast Atlantic, in waters $264 \mathrm{~m}$ deep, approximately $30 \mathrm{~km}$ from the shelf edge and $170 \mathrm{~km}$ from the Irish coast $\left(53.684^{\circ} \mathrm{N}, 12.755^{\circ} \mathrm{W}\right)$ (Fig. 1). The sighting was recorded during an opportunistic marine mammal ship board survey. Observations were carried out from the observation deck $12 \mathrm{~m}$ above sea level, with unrestricted views $120^{\circ}$ either side of the bow of the vessel. The vessel's median travel speed was $10 \mathrm{kn}$. Weather conditions at the time of the sighting were excellent: Beaufort sea state of 2, swell less than $1 \mathrm{~m}$, with no glare. The calf was initially sighted alone when it surfaced within $50 \mathrm{~m}$ of the starboard side of the vessel. On the calf's third surfacing, < $100 \mathrm{~m}$ from the vessel, it was accompanied by an adult whale. A positive identification of both animals was made at the time of the sighting and photographs were taken (Fig. 2). The adult was estimated to be c. $8 \mathrm{~m}$ in length, while the calf was substantially smaller at c. $2.5 \mathrm{~m}$ (Fig. 2)

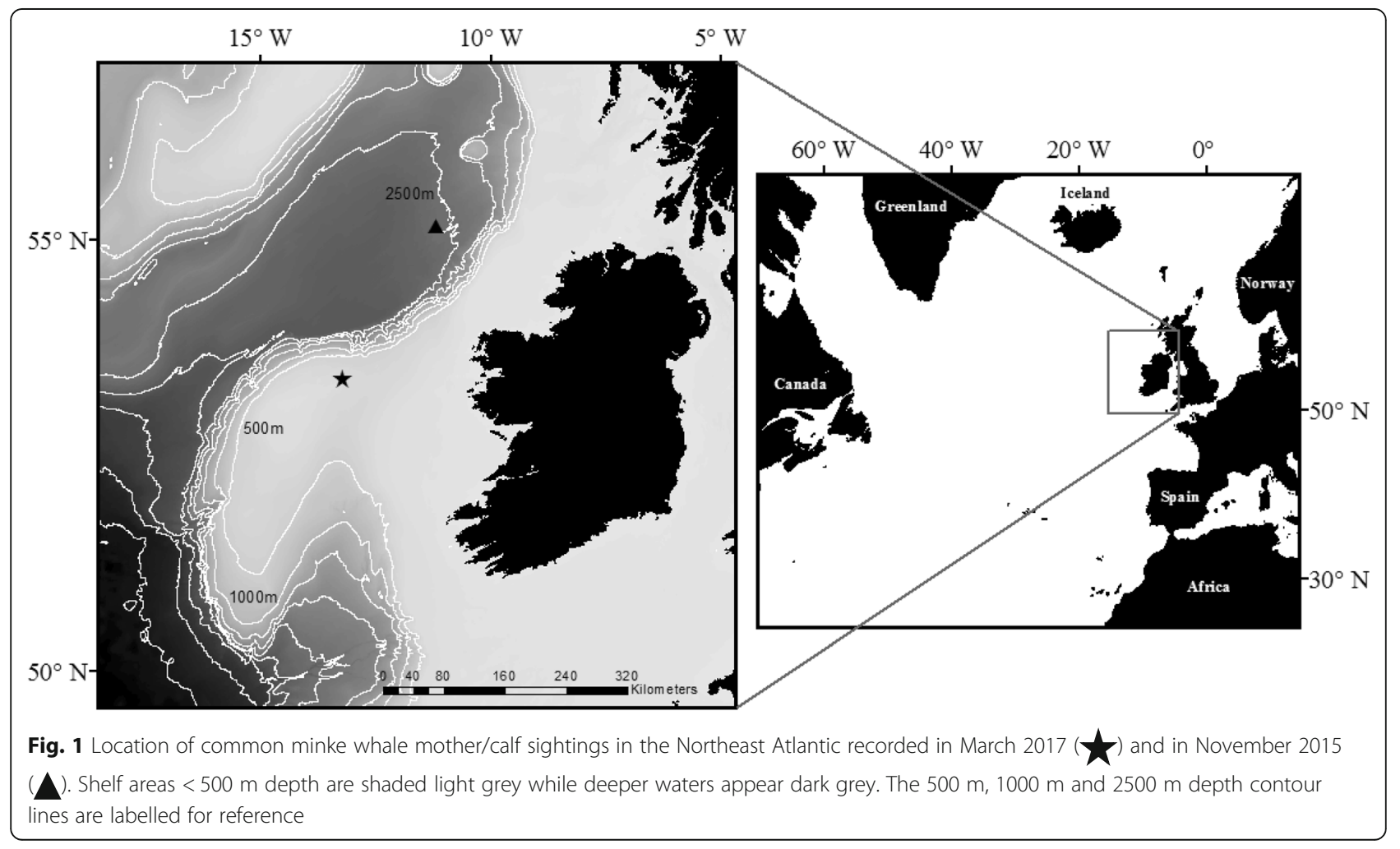




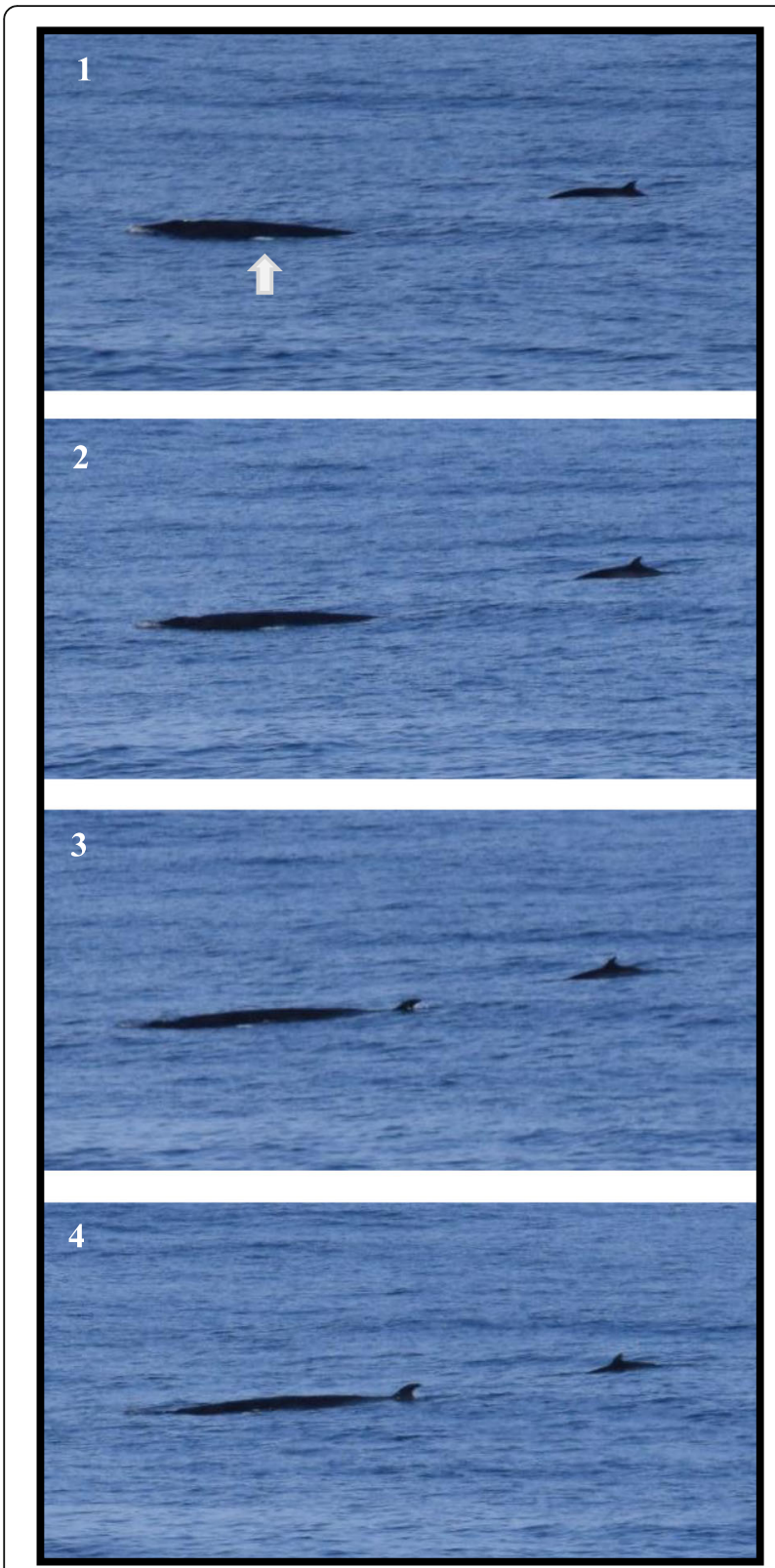

Fig. 2 Surfacing sequence during March 2017 sighting of common minke whale with calf. The characteristic white banding on the adult's left pectoral fin is visible at the water surface (indicated in panel 1 with a white arrow)

(sizes estimated by experienced observers, by eye, at close range). The timing of the sighting, and the small size of the animal, suggests that it was a very young dependent calf, less than 3 months old (Evans, 1987).

Another sighting of a minke whale accompanied by a calf was recorded in deep water $(2550 \mathrm{~m})$ approximately $70 \mathrm{~km}$ from the shelf edge and $150 \mathrm{~km}$ from the Irish coast $\left(55.523^{\circ} \mathrm{N}, 11.031^{\circ} \mathrm{W}\right)$ on 22 nd of November 2015 (Fig. 1). Weather conditions at the time were good; Beaufort sea state of 3, with no glare. This sighting was recorded during a dedicated cetacean and seabird aerial survey using a twin-engine, high-wing aircraft (Britten Norman Islander) flying at a height of $183 \mathrm{~m}$ and a speed of 90-100 kn. The aircraft was fitted with bubble windows to provide observers with unobstructed views of the sea surface directly below and abeam of the aircraft. A positive species identification was made by the observer at the time of the sighting, however, no photographs were taken. In this instance, the adult was estimated to be c. $8 \mathrm{~m}$, and the calf c. $3.5 \mathrm{~m}$ (sizes estimated by experienced observers, by eye). It is therefore probable that given the size of this calf, and an estimated nursing period of 5-6 months (Oftedal, 1997), this animal was also a young dependant calf.

Based on the timing of sightings and the sizes of the animals encountered, we believe the sightings reported here to be of unweaned minke whale calves. The location of the sightings, in relatively deep waters in the open ocean, is similar to sightings and/or acoustic detections recorded elsewhere (Risch et al., 2014; Folkow \& Blix, 1991; Nieukirk et al., 2004), possibly indicating offshore movement, and even calving and nursing, in winter and spring months. Vikingsson and Heide-Jørgensen (2015) recorded the first evidence of autumn migration routes and destination of common minke whales in the North Atlantic, however, the paradigm that all individuals within a mysticete species group (i.e. minke whales or humpback whales) undertake seasonal migrations between high and low latitudes has long been debated (Geijer et al., 2016; Corkeron \& Connor, 1999). The winter sightings presented here raise the possibility that, like other mysticete whale species (Craig \& Herman, 1997), not all minke whales in the Northeast Atlantic population undertake a long southerly migration to breeding grounds in equatorial waters annually.

There are a number of hypotheses for mysticete seasonal migration, including avoidance of predation by killer whales (Orcinus orca), resource tracking, and direct benefits to the calf (Corkeron \& Connor, 1999). The latter relates to calf growth and survivorship; that females calve in the warmer waters of lower latitudes to take advantage of thermal benefits to their calves (Corkeron \& Connor, 1999). Watts et al., (1993) suggested that minke whale neonates require waters of $14{ }^{\circ} \mathrm{C}$ to remain thermoneutral. The waters surrounding Ireland are greatly influenced by the North Atlantic Drift, a north-easterly-directed component of the Gulf Stream. The meeting of this warm water with the western European continental shelf results in warmer conditions than would be expected for waters of this latitude. According to satellite data from NOAA, the water temperatures at the time of the sightings of mother calf pairs in this study ranged between 12 and $13{ }^{\circ} \mathrm{C}$, close to the reported thermoneutral limit of $14{ }^{\circ} \mathrm{C}$ (Watts et al., 1993) which are more typically associated with areas proximate to the Bay 
of Biscay in the Northeast Atlantic at that time of year. The occurrence of what would be thermoneutral water conditions for minke calves in offshore western European continental shelf waters at this time of year could be one reason why some pregnant female minke whales might remain at these higher latitudes to calve.

Acoustic data collected in the Northwest and central Atlantic contributes to our understanding of minke whale offshore and winter distributions, especially in remote areas where visual survey effort is difficult to obtain (Risch et al., 2014; Nieukirk et al., 2004; Risch et al., 2013). However, as little is known about sex-specific or calf-specific minke whales vocalisations, identification of their breeding grounds using these data is difficult. In addition, low levels of visual survey effort year round, but particularly in winter and spring months, in the offshore waters of the Northeast Atlantic, coupled with low representative genetic sampling across the different regions of the North Atlantic (Anderwald \& Evans, 2007), has hindered the identification of calving and breeding areas for this species. Further sightings of adult minke whales during extensive aerial surveys over winter months support the hypothesis that minke whales are present in Irish waters throughout winter with a predominately-offshore distribution (unpublished data). The observations reported here extend the current northern range of minke whale calf sightings in winter into the Northeast Atlantic and raise the possibility that not all pregnant females migrate to very low latitudes in order to calf. The location and timing of these sightings highlight the need for increased visual and acoustic survey effort in offshore waters of the Northeast Atlantic to determine the movement patterns and potential breeding areas of minke whales.

\section{Abbreviations}

IUCN: International Union for Conservation of Nature; IWC: International Whaling Commission

\section{Acknowledgements \\ The authors would like to thank the crew of the R.V. Tridens who provided berths on research cruise for observers. We are grateful for the comments and suggestions received from referees, which improved this manuscript.}

\section{Funding}

The sightings described here were collected as part of (i) the ObSERVE Programme initiated in 2014 by Ireland's Department of Communication, Climate Action and Environment and the Department of Culture, Heritage and the Gaeltacht, and (ii) the SFI-KOSMOS project supported by SFI funding under Grant No. SFI/12/RC/2302 with industry partner funding from KOSMOS Energy. The funders of the ObSERVE programme partly designed the aerial line transects flown. The funders of the SFI-KOSMOS programme had no input into the design or implementation of the study.

Availability of data and materials

All data analysed during this study are included in this published article.

\section{Authors' contributions}

ASK, GK and NR had a substantial input into the aquisition of the data presented in the mauscript. ASK, GK, ER and MJ conceived the study and were involved in drafting the manuscript. All authors participated in discussion and editing of the manuscript. All authors read and approved the final manuscript.
Ethics approval and consent to participate

The sightings reported here were part of larger scale boat and aerial surveys for cetaceans, which do not require ethical approval.

Consent for publication

Not applicable.

\section{Competing interests}

The authors declare that they have no competing interests.

\section{Publisher's Note}

Springer Nature remains neutral with regard to jurisdictional claims in published maps and institutional affiliations.

\section{Author details}

${ }^{1}$ MaREl Centre, Environmental Research Institute, University College Cork, Beaufort Building, Ringaskiddy, Co, Cork, Ireland. ${ }^{2}$ School of Biological, Earth and Environmental Sciences, University College Cork, Enterprise Centre, North Mall, Distillery Fields, Cork, Ireland. ${ }^{3}$ Marine Institute, Rinville, Oranmore, Co, Galway, Ireland.

Received: 1 August 2018 Accepted: 14 September 2018

Published online: 16 October 2018

\section{References}

Anderwald P, Daníelsdóttir AK, Haug T, Larsen F, Lesage V, Reid RJ, et al. Possible cryptic stock structure for minke whales in the North Atlantic: implications for conservation and management. Biol Conserv. 2011;144(10):2479-89.

Anderwald P, Evans GH. Minke whale populations in the North Atlantic: an overview with special reference to UK waters. In: Robinson KP, Stevick PT, MacLeod CD, editors. An Integrated Approach to Non-lethal Research on Minke Whales in European Waters European Cetacean Society Spec Public Series 47; 2007. p. 8-13.

Bartha GB, Gowans S, Simard P, Tetley M, Keith EO. Population size and site Fidelity of North Atlantic Minke whales (Balaenoptera acutorostrata acutorostrata) off the Atlantic Coast of Nova Scotia, Canada. Aquat Mamm. 2011;37(4):454-63.

Bertulli CG, Guéry L, McGinty N, Suzuki A, Brannan N, Marques T, et al. Capturerecapture abundance and survival estimates of three cetacean species in Icelandic coastal waters using trained scientist-volunteers. I Sea Res. 2018; 131:22-31.

Christensen I. Age determination of minke whales, Balaenoptera acutorostrata, from laminated structures in the tympanic bullae. Rep Int Whal Commn. 1981;31:245-53.

Corkeron PJ, Connor RC. Why do baleen whales migrate? Mar Mamm Sci. 1999; 15(4):1228-45.

Craig AS, Herman LM. Sex differences in site fidelity and migration of humpback whales (Megaptera novaeangliae) to the Hawaiian islands. Can J Zool. 1997; 75(11):1923-33.

De Boer M. Spring distribution and density of minke whale Balaenoptera acutorostrata along an offshore Bank in the central North Sea. Mar ecol Prog Ser. 2010;408:265-74

Donovan GP. A review of IWC stock boundaries. Rep int Whal Commn. 1991;13: 39-68.

Evans P. The natural history of whales and dolphins. Facts on file. Inc, New York. In: New York; 1987.

Folkow L, Blix A. Norwegian whale sighting and acoustic surveys in the Atlantic Ocean during the winter of 1989/90. Rep Int Whal Comm 1991. 1991;41:531-8.

Fraija-Fernández N, Crespo-Picazo JL, Domènech F, Míguez-Lozano R, PalaciosAbella JF, Rodríguez-González A, et al. First stranding event of a common Minke whale calf, Balaenoptera acutorostrata Lacépède, 1804, reported in Spanish Mediterranean waters. Mamm Study. 2015;40(2):95-100.

Geijer CKA, di Sciara GN, Panigada S. Mysticete migration revisited: are Mediterranean fin whales an anomaly? Mammal Rev. 2016:46(4):284-96.

Hammond P, Berggren P, Benke H, Borchers D, Collet A, Heide-Jørgensen M, et al. Abundance of harbour porpoise and other cetaceans in the North Sea and adjacent waters. J Appl Ecol. 2002;39(2):361-76.

Hammond PS, Macleod K, Berggren P, Borchers DL, Burt L, Cañadas A, et al. Cetacean abundance and distribution in European Atlantic shelf waters to inform conservation and management. Biol Conserv. 2013;164:107-22. 
Hauksson E, Víkingsson GA, Halldorsson SD, Olafsdottir D, Sigurjónsson J. Preliminary report on biological parameters for NA minke whales in Icelandic waters. In: Report of the international whaling commission 63: 1-45; 2011.

Horwood JW. Biology and exploitation of the minke whale: CRC press; 1989.

IWC. Report of the Scientific Committee SC/67b. 2018.

Laran S, Authier M, Blanck A, Doremus G, Falchetto H, Monestiez P, et al. Seasonal distribution and abundance of cetaceans within French waters- part II: the Bay of Biscay and the English Channel. Deep-Sea Res II Top Stud Oceanogr. 2017;141:31-40

Larsen F, Kapel F. Norwegian minke whaling off West Greenland, 1976-80 and biological studies of West Greenland minke whales. Rep Int Whal Commn. 1982;32:263-83.

Lockyer C. Estimation of the energy costs of growth, maintenance and reproduction of the female minke whale Balaenoptera acutorostrata from the Southern Hemisphere; 1981. p. 337-43.

Lockyer C. Review of Baleen Whale (Mysticeti) Reproduction and Implications for Management; 1984. p. 27-50.

Macleod K, Fairbairns R, Gill A, Fairbairns B, Gordon J, Blair-Myers C, et al. Seasonal distribution of minke whales Balaenoptera acutorostrata in relation to physiography and prey off the Isle of Mull, Scotland. Mar Ecol Prog Ser. 2004; 277:263-74.

Mitchell ED. Winter records of the minke whale (Balaenoptera acutorostrata acutorostrata Lacepede 1804) in the southern North Atlantic. Rep Int Whal Comm 1991. 1991:41:455-7.

Nieukirk SL, Stafford KM, Mellinger DK, Dziak RP, Fox CG. Low-frequency whale and seismic airgun sounds recorded in the mid-Atlantic Ocean. J Acoust Soc Am. 2004;115(4):1832-43.

Nilsson P, Cummings E, Foley H, Hardee R, Holt R, McAlarney R, et al. Recent winter sightings of Minke whales (Balaenoptera acutorostrata) in the South Atlantic bight. In proc of the 19th Bienn mar mammal Conf, Soc for mar mammal Tampa, Florida. USA. 2011;2011:1,

Oftedal OT. Lactation in whales and dolphins: evidence of divergence between baleen- and toothed-species. J Mammary Gland Biol Neoplasia. 1997;2(3):205-30.

Quintela M, Skaug HJ, Øien N, Haug T, Seliussen BB, Solvang HK, et al. Investigating population genetic structure in a highly Mobile marine organism: the Minke whale Balaenoptera acutorostrata acutorostrata in the north East Atlantic. PLoS One. 2014:9(9):e108640.

Reilly SB, Bannister JL, Best PB, Brown M, Brownell RL Jr, Butterworth DS, et al. Balaenoptera acutorostrata. The IUCN Red List of Threatened Species. 2008: eT2474A9444043. https:/doi.org/10.2305/UCN.UK.2008.RLTS.T2474A9444043.en.

Risch D, Castellote M, Clark CW, Davis GE, Dugan PJ, Hodge LE, et al. Seasonal migrations of North Atlantic minke whales: novel insights from large-scale passive acoustic monitoring networks. Mov Ecol. 2014;2(1):24.

Risch D, Clark CW, Dugan PJ, Popescu M, Siebert U, Van Pariis SM. Minke whale acoustic behavior and multi-year seasonal and diel vocalization patterns in Massachusetts Bay, USA. Mar Ecol Prog Ser. 2013:489:279-95.

Sergeant DE. Minke whales, Balaenoptera acutorostrata Lacépède, of the Western North Atlantic. J Fish Res Board Can. 1963;20(6):1489-504.

Skaug HJ, Øien N, Schweder T, Bøthun G. Abundance of minke whales (Balaenoptera acutorostrata) in the Northeast Atlantic: variability in time and space. Can J Fish Aquat Sci. 2004;61(6):870-86.

Vikingsson GA, Heide-Jørgensen MP. First indications of autumn migration routes and destination of common minke whales tracked by satellite in the North Atlantic during 2001-2011. Mar Mamm Sci. 2015;31(1):376-85.

Watts P, Hansen S, Lavigne DM. Models of heat loss by marine mammals: thermoregulation below the zone of irrelevance. J Theor Biol. 1993;163(4): $505-25$.

Ready to submit your research? Choose BMC and benefit from:

- fast, convenient online submission

- thorough peer review by experienced researchers in your field

- rapid publication on acceptance

- support for research data, including large and complex data types

- gold Open Access which fosters wider collaboration and increased citations

- maximum visibility for your research: over $100 \mathrm{M}$ website views per year

At $\mathrm{BMC}$, research is always in progress.

Learn more biomedcentral.com/submissions 